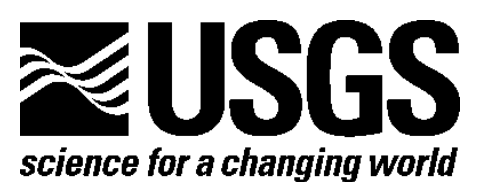

\title{
Assessment of Photographs from Wildlife Monitoring Cameras in Drakes Estero, Point Reyes National Seashore, California
}

By William A. Lellis, Carrie J. Blakeslee, Laurie K. Allen, Bruce F. Molnia, Susan D. Price, Sky Bristol, and Brent Stewart

Open-File Report 2012-1249

U.S. Department of the Interior

U.S. Geological Survey 


\section{U.S. Department of the Interior \\ KEN SALAZAR, Secretary}

\section{U.S. Geological Survey \\ Marcia K. McNutt, Director}

U.S. Geological Survey, Reston, Virginia: 2012

For more information on the USGS—-the Federal source for science about the Earth, its natural and living resources, natural hazards, and the environment-visit http://www.usgs.gov or call 1-888-ASK-USGS

For an overview of USGS information products, including maps, imagery, and publications, visit $h$ ttp://www.usgs.gov/pubprod

To order this and other USGS information products, visit http://store.usgs.gov

Suggested citation:

Lellis, W.A., Blakeslee, C.J., Allen, L.K., Molnia, B.F., Price, S.D., Bristol, Sky, and Stewart, Brent, 2012,

Assessment of photographs from wildlife monitoring cameras in Drakes Estero, Point Reyes National Seashore, California: U.S. Geological Survey Open-File Report 2012-1249, 24 p., available only at http://pubs.usgs.gov/of/2012/1249.

Any use of trade, firm, or product names is for descriptive purposes only and does not imply endorsement by the U.S. Government.

Although this information product, for the most part, is in the public domain, it also may contain copyrighted materials as noted in the text. Permission to reproduce copyrighted items must be secured from the copyright owner. 


\section{Contents}

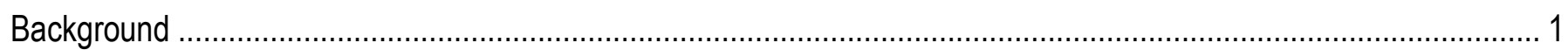

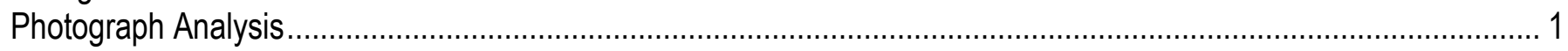

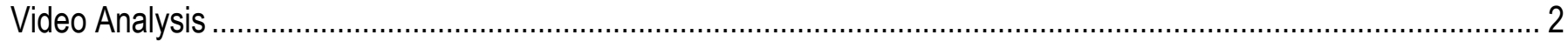

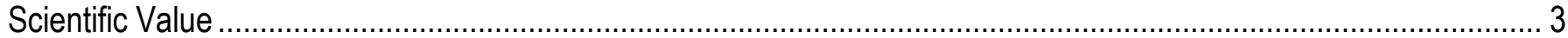

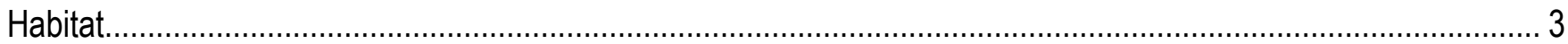

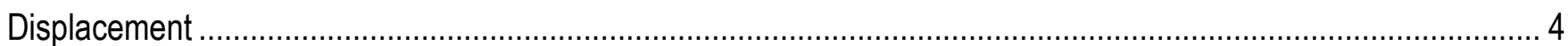

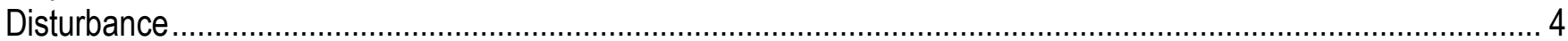

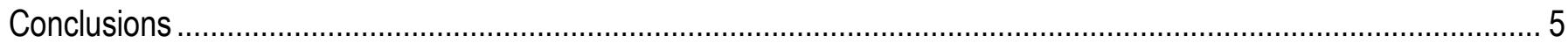

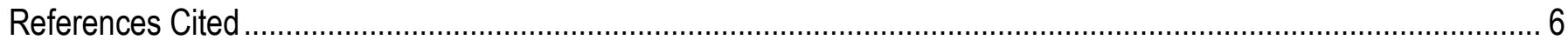

Appendix 1. Summary analysis of 3,140 photographs from 75 potential disturbance events to hauled out harbor

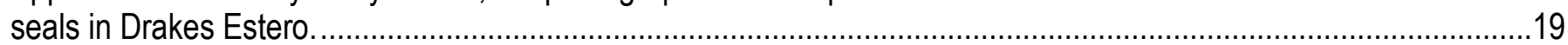

\section{Figures}

1. Sample of photographs from Point Reyes monitoring cameras ................................................................. 8

2. A series of photographs of a seal flushing event on March 31, 2008, at the Oyster Bar site within Drakes Estero.

3. A series of photographs of a seal flushing event on April 13, 2008, beginning at 12:01 p.m. at the Oyster Bar site within Drakes Estero.

4. A series of photographs of a seal flushing event on April 13, 2008, beginning at 12:29 p.m. at the Oyster Bar site within Drakes Estero.

5. A series of photographs of a seal flushing event on April 14, 2008, at the Oyster Bar site within Drakes Estero.

6. A series of photographs of a seal flushing event on April 23, 2008, at the Oyster Bar site within Drakes Estero

7. A series of photographs of a seal flushing event on May 6, 2008, at the Oyster Bar site within Drakes Estero.

8. A series of photographs of a seal flushing event on May 15, 2008, at the Oyster Bar site within Drakes Estero

9. A series of photographs of a seal flushing event on May 31, 2008, at the Oyster Bar site within Drakes Estero.

10. A series of photographs of a seal flushing event on June 2, 2008, at the Oyster Bar site within Drakes Estero.

11. A series of photographs of a seal flushing event on June 11, 2008, at the Oyster Bar site within Drakes Estero

\section{Tables}

1. Flushing events of Drakes Estero seals identified in 2008 National Park Service photographs 


\title{
Assessment of Photographs from Wildlife Monitoring Cameras in Drakes Estero, Point Reyes National Seashore, California
}

\author{
By William A. Lellis, ${ }^{1}$ Carrie J. Blakeslee, ${ }^{1}$ Laurie K. Allen, ${ }^{1}$ Bruce F. Molnia, ${ }^{1}$ Susan D. Price, ${ }^{1}$
} Sky Bristol, ${ }^{1}$ and Brent Stewart²

\section{Background}

Between 2007 and 2010, National Park Service (NPS) staff at the Point Reyes National Seashore, California, collected over 300,000 photographic images of Drakes Estero from remotely operated wildlife monitoring cameras. The purpose of the systems was to obtain photographic data to help understand possible relationships between anthropogenic activities and Pacific harbor seal (Phoca vitulina richardsi) behavior and distribution.

The value of the NPS photographs for use in assessing the frequency and impacts of seal disturbance and displacement in Drakes Estero has been debated. In September 2011, the NPS determined that the photographs did not provide meaningful information for development of a Draft Environmental Impact Statement (DEIS) for the Drakes Bay Oyster Company Special Use Permit. Limitations of the photographs included lack of study design, poor photographic quality, inadequate field of view, incomplete estuary coverage, camera obstructions, and weather limitations.

The Marine Mammal Commission (MMC) reviewed the scientific data underpinning the Drakes Bay Oyster Company DEIS in November 2011 and recommended further analysis of the NPS photographs for use in characterizing rates and consequences of seal disturbance (Marine Mammal Commission, 2011). In response to that recommendation, the NPS asked the U.S. Geological Survey (USGS) to conduct an independent review of the photographs and render an opinion on the utility of the remote camera data for informing the environmental impact analyses included in the DEIS.

In consultation with the NPS, we selected the 2008 photographic dataset for detailed evaluation because it covers a full harbor seal breeding season (March 1 to June 30), provides two fields of view (two cameras were deployed), and represents a time period when cameras were most consistently deployed and maintained. The NPS requested that the photographs be evaluated in absence of other data or information pertaining to seal and human activity in the estuary and that we focus on the extent to which the photographs could be used in understanding the relationship between human activity (including commercial oyster production) and harbor seal disturbance and distribution in the estuary.

\section{Photograph Analysis}

The NPS provided 333,042 digital photographs of the Drakes Estero taken by remote cameras between 2007 and 2010. These same photographs are available to the public on the Point Reyes

\footnotetext{
${ }^{1}$ U.S. Geological Survey

${ }^{2}$ Hubbs-Seaworld Research Institute, San Diego, Calif.
} 
National Seashore Reading Room Web site (NPS Reading Room, 2012; Web address listed in References Cited). Included in the collection were 165,282 photographs taken in 2008 from two sites within Drakes Estero: 100,457 from a site referred to as the Upper Estero Far (UEF) and 64,825 from a site referred to as the Oyster Bar (OB). These photographs were taken between March 14 and June 23, 2008, at an interval of one per minute during daylight hours (approximately 720 photographs per day at each site). Some of these photographs were duplicates.

Our initial plan was to analyze a random subsample of 10 percent of all 2008 photographs and assess each individual photograph for quality and information that could be used to study seal disturbance and displacement. Such information would include photograph clarity and resolution, obstructions, field of view, light, weather conditions, stage of tide, presence and number of seals, human activity, nonhuman activity, and evidence of seal disturbance. Seal disturbance was classified as head alert (increased vigilance), flushing on land (change in position), or flushing into water (abandon site). (See Marine Mammal Commission (2011, p. 13-16) for additional discussion.)

Initial review of a portion of the intended subsample indicated that many photographs were of no obvious value to understanding seal behavior during haulout because of inadequate light, inadequate observing conditions due to weather (fog, rain, wind), obstructions (plants), too wide a field of view, misdirection of camera, wrong tidal stage (no exposed sand bars for haulout), and (or) no seals within camera view (fig. 1). A smaller portion of the photographs contained potentially useful information such as exposed sandbars, presence of hauled out seals, and (or) potentially disturbing stimuli such as boats, people, birds, or other unidentified objects in the water, sky, or on land.

Within the photographs that contained hauled out seals, the distance of the camera from the seals was often too great, the angle of the camera too low to the water, and resolution of the photographs too low to allow an accurate count of the number of individual seals within groups hauled out on the sand. Nor was it possible, in most cases, to distinguish any behaviors among individual seals, such as head alerts, that could definitively be ascribed to increased vigilance in response to a stimulus. These same limitations also prevented determination of any distinguishing features that would allow for identification of specific boats or people, or activities in which they were engaged. Attempts to improve resolution through photographic enhancements were unsuccessful.

\section{Video Analysis}

Our initial approach of analyzing a random subsample of all photographs had two significant limitations. The first was that information contained within each photograph lacked the context of how it fit into events that occurred immediately before and after that moment in time. This lack of sequential information effectively prevented determination of seal flushing (change in number of seals over time) or the reasonable establishment of cause and effect between seal behavior and human or nonhuman activity. The second limitation was that examination of individual photographs was extremely time consuming and yielded little usable information for the given effort. As such, we changed our approach to animation of photographs into daily videos to allow more rapid screening and to add sequential context to each photograph.

To make the videos, we retrieved the 2008 photographs from the Point Reyes National Seashore Reading Room Web site using a utility that can copy a site's pages, images, movies, and other files. Each image on the Web site was dated and time-stamped. Although the NPS cameras were programmed to take one photograph every minute for 12 hours ( 720 photographs per day), camera malfunction, battery failure, changes in camera programming, or other technical issues resulted in some days containing more or less than 720 photographs. Missing photographs for specific dates and times were verified as nonexistent with Point Reyes staff. 
After retrieval, we added the file name to each image as a watermark and imported the files into Apple iPhoto for production. The interval between frames (that is, photographs) was set to 1 second with no transition effects, in order to create a time-lapse style video. No photographs were edited from their original form or deleted during production. Videos were exported as MPEG4 files, which retained each photograph's original resolution. All videos can be downloaded from the USGS Applied Earth Systems Web site (Web address listed in References Cited).

Each video was reviewed by at least two observers working together to identify and record data of possible interest in an analysis of seal disturbance, including time of day when the sand bars appeared and disappeared, time of day when seals hauled onto or left a sandbar, human activity when seals were present, nonhuman activity when seals were present, and any abrupt changes in the size or location of a group or the number of seals hauled out on a sand bar. Within each video, human activity was recorded only during times when seals were hauled onto sandbars (that is, boat traffic was not recorded during high tide or when seals were not present on the sand bars).

In total, we produced 191 videos from the 2008 photographic collection (103 UEF, 88 OB). No hauled out seals were detected in any of the UEF videos, because of low resolution and wide field of camera view, so we conducted no further analyses of those pictures. Within the OB videos, we identified 75 different events (appendix 1) in which human activity was visible in the photographs while seals were hauled out, or there was an unusual amount of nonhuman stimuli (birds), or there was a sudden change in the number or position of hauled seals. Human activity during seal haulout included boats (44 events, 34 of which had people visible on the sand bars while the boat was stationary), camera maintenance ( 21 events), and kayaks ( 2 events). We detected camera service by either a change in camera angle or a reset in the image number during a daily photograph sequence.

Photographic sequences of each event, plus the 10 photographs before the start of each event and the 10 photographs after the end of each event $(3,140$ photographs total) were analyzed for incidence and cause of seal disturbance. Ten of the 75 events were classified as containing behaviors indicative of disturbance in the form of flushing (table 1, figs. 2-11, appendix 1). Two flushing events were associated with the presence of a kayak, two were associated with birds landing in the area, two were associated with boat activity, and four occurred when no obvious stimuli were visible within the field of view of the camera.

\section{Scientific Value}

Using the analysis we conducted of the 2008 Drakes Estero photographs as a representative sample of all 4 years of monitoring, we considered the scientific value of these photographs without other supporting information for use in analyses to determine the impacts of human and nonhuman activities on seal habitat, displacement, or disturbance.

\section{Habitat}

Fitness is defined as a measure of an individual seal's ability to survive and reproduce and is influenced by many factors, including suitable haulout habitat for resting, molting, and reproduction, particularly for females and pups during the spring breeding season (Marine Mammal Commission 2011, p. 13). Suitable haulout sites provide quick access to deep water for shelter, protection from storm events and predators, and minimization of disturbance and harassment. In that regard, monitoring cameras can provide site-specific information on habitat persistence over time; physical impact of weather, storms, and waves; occupancy rate; frequency and severity of harassment from predators such as coyotes and elephant seals; frequency and severity of disturbance from human and nonhuman 
sources; and a general sense of degree of comfort seals have with a site (degree to which they maintain a resting position during haulout).

The 2008 Drakes Estero photographs can provide information on habitat persistence and use at the OB site. The photographs have adequate resolution, time and date-stamping, field of view, and span of operation to determine daily timing and duration of sand bar exposure, storm damage and wave conditions, frequency and timing of site usage, and how weather and tidal cycles affect site occupation. Data on sand bar exposure could be related to local tidal gages to develop predictive models of daily habitat timing and availability within the estuary.

Limitations of the 2008 photographs for habitat monitoring include lack of information during darkness, limited information during low visibility conditions such as fog, inconsistent or limited ability to count animals or estimate age for use in occupancy estimates, lack of information on concurrent use of other haulout sites, and inadequate resolution to identify specific predators on land or in the water (see 3/31/08 and 5/1/08 in appendix 1). Habitat monitoring could be improved by installation of highdefinition cameras, multiple cameras with different focal lengths and field of view, and cameras capable of detecting animals during darkness.

\section{Displacement}

Displacement is defined as the avoidance of an otherwise preferred haulout site based on experience or perception of a possible threat (Marine Mammal Commission, 2011, p. 15). The 2008 OB monitoring camera provides a view of an area that simultaneously contains both hauled seals in the foreground and human activity in the form of boat traffic in water and foot traffic on submerged and exposed sandbars in the background. No seals were observed to be hauled out at any time in the area of human traffic in the photographs examined during this analysis. Thus, two questions on seal displacement can be raised for this site: are seals being completely displaced from the distant sandbars due to direct human activity and are seals being partially displaced from the closer sandbars due to indirect human activity? Answering these questions requires accurate counts of hauled seals over time and distance and a means of comparing occupancy rates during periods of human activity and no human activity.

Wildlife monitoring cameras can be used to study displacement by providing data on seal abundance and distribution over time in the presence and absence of human activity. The resolution of the 2008 OB photographs, however, is too low to provide consistently accurate counts of individual seals for this purpose. In addition, resolution diminishes with distance from the camera, thus creating an inherent bias to detect more seals in the foreground (site of haulout) than in the background (site of human activity). Monitoring to study seal displacement could be improved by installation of higher resolution cameras with greater image capture rate to increase accuracy of seal counts and by installation of cameras at multiple locations or with different focal lengths to remove distance sampling bias. Implementation of a statistically valid experimental design that controls human activity relative to variations in seal haulout activity over season, tide, and weather would also improve accuracy of displacement studies.

\section{Disturbance}

Disturbance is defined as an event or stimulus that alters a seal's behavior or use of estuary habitat for resting, molting, or reproduction (Marine Mammal Commission, 2011, p. 13). Disturbed seals may show a continuum of responses to disturbance, including vocalizations, increased vigilance such as raised head (head alert), change in position on land (flush toward water), flush into water and return, and flush into water and not return (abandon site). 
The 2008 OB photographs lack sound, so they do not provide any information on vocalizations. Within some photographs, there is enough resolution to detect changes in head position in individual seals (see OB-05-15-08 IMG_1599-1601). However, the ability to detect change is inconsistent across photographs and position of seals within the photographs, so for practical purposes the resolution is too coarse in the 2008 OB photographs to document the more subtle indicators of seal disturbance. The photographs can be used to document the more coarse indicators of disturbance, including flush toward water (see OB-06-11-2008 IMG_1155-1158), flush into water and return (see OB-04-13-2008 IMG_2190-2219), and abandon site (see OB-03-31-2008 IMG_0018-0050). Documentation of disturbance events would be greatly enhanced with increased resolution and multiple camera angles.

Within the 2008 OB videos, we identified 10 incidents of seal disturbance that involved a flushing event (table 1, figs. 2-11, appendix 1). This does not include all incidents of disturbance, because we could not include vocalizations, nor could we consistently detect head alerts and other postural changes indicating increased vigilance. It is also possible that we missed incidents of flushing, particularly those involving changes in position on land within large groups of seals at distances farthest from the camera.

Correlation of these flushing events with specific stimuli was difficult due to lack of associated sound, coarse resolution, and limited field of view on land, water, and air. Three types of stimuli that could be directly connected, or at least associated with a flushing level of disturbance in the OB seals are kayaks passing in proximity (see OB-04-13-2008 IMG_2186-2200 and OB-04-13-2008 IMG_22182224), seabirds landing among or close to the seals or passing nearby (see OB-04-14-2008 IMG_03540359 and OB-04-23-2008 IMG_1315-1322), and boat traffic at nearby sandbars (see OB-05-15-2008 IMG_1590-1605 and OB-06-11-2008 IMG_1153-1163). However, there are numerous incidents of increased seabird activity in the photographs with no indication of flushing-level disturbance to seals. We recorded 40 incidents of boat visits to the adjacent sandbar (many with related foot traffic) that did not seem to cause a flushing-level disturbance in the hauled seals, and at times there are multiple sources of potential disturbance stimuli occurring simultaneously. We found no evidence that activities related to maintenance of the remote camera system directly caused any flushing-level disturbances in the seals, although the relationship between camera maintenance and bird movement could not be ascertained by these photographs.

\section{Conclusions}

Based on our analysis of 165,282 photographs taken in 2008 from two remote cameras within

Drakes Estero, we conclude that the protocols used by the NPS camera monitoring program did provide some data that could be used to document gross haulout patterns of seals and some instances of reactions to potential stimuli in the Drakes Estero. Data are limited to seal use of the Oyster Bar site related to time, tide, and weather and to some coarse detection of disturbance as measured by flushing of seals from resting positions toward or into the water. The length of time that seals abandoned the haulout sites after flushing could also be quantified in these photographs.

Camera focus was generally too poor and image resolution was too low to allow accurate counting or aging of seals or to provide enough anatomical detail to quantify postures associated with increased vigilance to potentially disturbing stimuli. The methods and equipment used did not allow discrimination between visual and auditory elements of potentially disturbing stimuli, and the field of view was too narrow to discriminate causation from correlation between seals and observed visual stimuli for most disturbance events. A wide-angle camera system with higher image resolution capabilities, or a network of linked high-resolution cameras coupled with audio recording systems would help determine whether movements or subtle changes in the behavior and posture of harbor seals 
is directly caused by human disturbance. The systems would also provide better opportunities for recording normal haulout patterns and behaviors.

Direct monitoring by on-site observers would allow better documentation and evaluation of seal behaviors and the variables that influence them, provided that the observers themselves do not create additional potential for seal disturbance, such as flushing of birds into the seal haulout area. A video and audio monitoring system that could broadcast continuously by radio frequency, cellular telephone, or satellite to a remote site would reduce the chances that operation of photographic equipment could confound the observations. That system would need to resolve the same issues of focus, field of view, angle, and resolution that have limited the utility of the time-lapse camera system used in 2008.

The first order limitation of all these methods is that they only document the brief response or non-response of harbor seals to a single potentially correlative stimulus. Larger scale questions on the significance of disturbance events to seal behavior within Drakes Estero, or the relationship of localized seal disturbances to overall population structure and viability, require rigorous investigation and hypothesis testing. If hypothesis testing and discrimination of causation from correlation is the intent of further effort at Point Reyes, then development of a more rigorous and comprehensive study design to incorporate several behavioral and environmental monitoring methods is needed.

\section{References Cited}

Applied Earth Systems Informatics Research (AESIR), 2012, PRNS time lapse videos: Web site accessed September 2012 at https://my.usgs.gov/confluence/display/aesir/PRNS+Time+Lapse+Videos.

Marine Mammal Commission, 2011, Mariculture and harbor seals in Drakes Estero, California: A report by the Marine Mammal Commission, November 22, 2011, available at http://mmc.gov/drakes_estero/pdfs/drakes_estero_report.pdf.

National Park Service Reading Room, 2012, Photographs_-Drakes Estero wildlife monitoring cameras - 2008: Web site accessed September 2012 at http://www.nps.gov/pore/parkmgmt/planning_reading_room_photographs_wmc_de_2008.htm. 


\begin{tabular}{|c|c|c|c|c|c|}
\hline Date & Video File Name & Time & $\begin{array}{l}\text { NPS Web } \\
\text { site Folder }\end{array}$ & $\begin{array}{l}\text { Image File } \\
\text { Name }\end{array}$ & Notes \\
\hline $03 / 31 / 08$ & OB-03-31-2008-Large.m4v & 1:57 p.m. & $\begin{array}{l}\text { March 31- } \\
\text { April } 2\end{array}$ & IMG 0026 & $\begin{array}{l}\text { Unidentified black object appears in single image (IMG_0023) } 3 \text { min prior to } \\
\text { all seals flushing into the water; seals do not return to haulout site for the } \\
\text { remainder of the tide. }\end{array}$ \\
\hline $04 / 13 / 08$ & OB-04-13-2008-Large.m4v & 12:04 p.m. & $\begin{array}{l}\text { April 10- } \\
\text { April } 14\end{array}$ & IMG_2195 & $\begin{array}{l}\text { Kayak becomes visible in vicinity of seals at } 11: 55 \text { a.m. (IMG_2186); } 9 \text { min } \\
\text { later all seals flush into the water as kayak passes haulout site; seals return to } \\
\text { site } 6 \text { min after flushing (IMG_2201.) }\end{array}$ \\
\hline $04 / 13 / 08$ & OB-04-13-2008-Large.m4v & 12:32 p.m. & $\begin{array}{l}\text { April 10- } \\
\text { April } 14\end{array}$ & IMG_2223 & $\begin{array}{l}\text { Kayak becomes visible in vicinity of seals at 12:28 p.m. (IMG_2219); } 4 \text { min } \\
\text { later all but } 2 \text { seals flush into the water. }\end{array}$ \\
\hline $04 / 14 / 08$ & OB-04-14-2008-Large.m4v & 6:20 p.m. & $\begin{array}{l}\text { April 14- } \\
\text { April } 17\end{array}$ & IMG_0355 & $\begin{array}{l}\text { Unidentified birds land on sandbar at 6:19 PM (IMG_0354); } 1 \text { min later some } \\
\text { seals flush into the water; some seals remain on sandbar }\end{array}$ \\
\hline $04 / 23 / 08$ & OB-04-23-2008_Large.m4v & 1:14 p.m. & $\begin{array}{l}\text { April 23- } \\
\text { April 25 }\end{array}$ & IMG_1319 & $\begin{array}{l}\text { Boat becomes visible at 1:09 p.m. (IMG_1314); people walk on sandbar; bird } \\
\text { activity near seals increase; } 5 \text { min after boat becomes visible birds land on } \\
\text { sandbar and some seals flush into the water; some seals remained hauled out } \\
\text { during event. }\end{array}$ \\
\hline 05/06/08 & OB-05-06-2008_Large.m4v & 10:19 a.m. & $\begin{array}{l}\text { May 5- } \\
\text { May } 7\end{array}$ & IMG_0675 & $\begin{array}{l}\text { Boat becomes visible at approximately 8:57 a.m. (IMG_0593); many seals } \\
\text { flush around } 80 \text { min later; some seals return within } 10 \text { min; boat remained on } \\
\text { sand bar }>7 \text { hours. }\end{array}$ \\
\hline 05/15/08 & OB-05-15-2008_Large.m4v & 2:07 p.m. & $\begin{array}{l}\text { May } 13- \\
\text { May } 15\end{array}$ & IMG_1603 & $\begin{array}{l}\text { Boat becomes visible at 1:55 p.m. (IMG_1591); people walk on sandbar; boat } \\
\text { leaves area at 2:06 p.m. (IMG_1602); some seals flush into water } 1 \text { min later. }\end{array}$ \\
\hline $05 / 31 / 08$ & OB-05-31-2008-Large.m4v & 7:32 a.m. & $\begin{array}{l}\text { May 29- } \\
\text { June } 2 \\
\end{array}$ & IMG_0951 & All but one seal flush into water; no visible human activity. \\
\hline $06 / 02 / 08$ & OB-06-02-2008-Large.m4v & 7:11 a.m. & $\begin{array}{l}\text { May 29- } \\
\text { June } 2\end{array}$ & IMG_2370 & $\begin{array}{l}\text { All seals flush into water; no visible human activity; some seals returned to } \\
\text { site approximately } 1 \text { hour later (IMG_2438) }\end{array}$ \\
\hline $06 / 11 / 08$ & OB-06-11-2008-Large.m4v & 11:25 a.m. & $\begin{array}{l}\text { June 9- } \\
\text { June } 12\end{array}$ & IMG 1157 & $\begin{array}{l}\text { A portion of hauled seals flush toward water at 11:25 a.m., } 3 \text { min prior to boat } \\
\text { arrival (IMG_1160); people seen walking on sandbar; seals remained hauled } \\
\text { out during event. }\end{array}$ \\
\hline
\end{tabular}




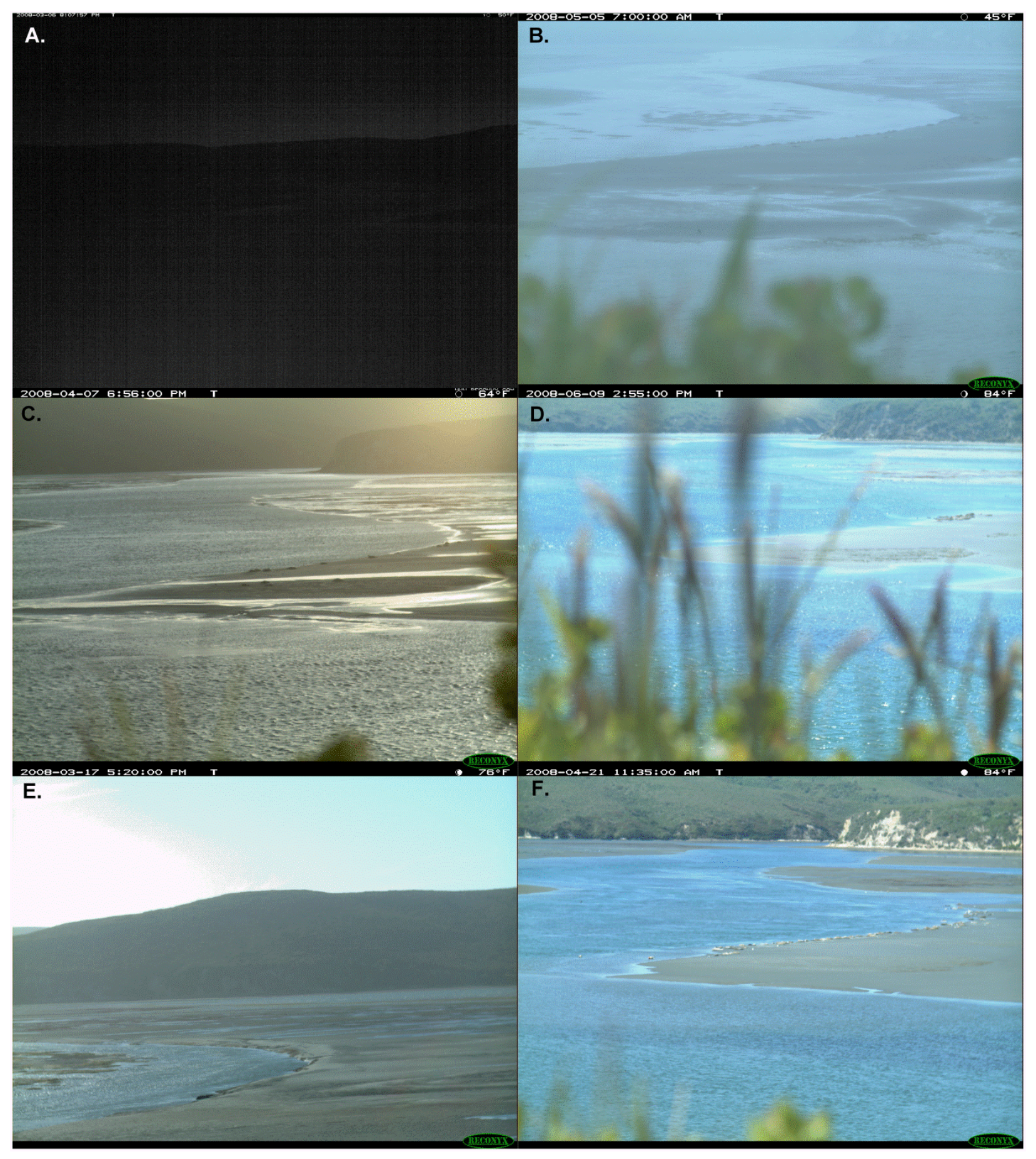

Figure 1. Sample of photographs from Point Reyes monitoring cameras, 2008, showing different conditions in the estuary. A, Nighttime. B, Foggy. C, Windy. D, Calm, with grass obstruction, E, Exposed sandbars, no seals. F, Exposed sandbars with seals hauled out. 


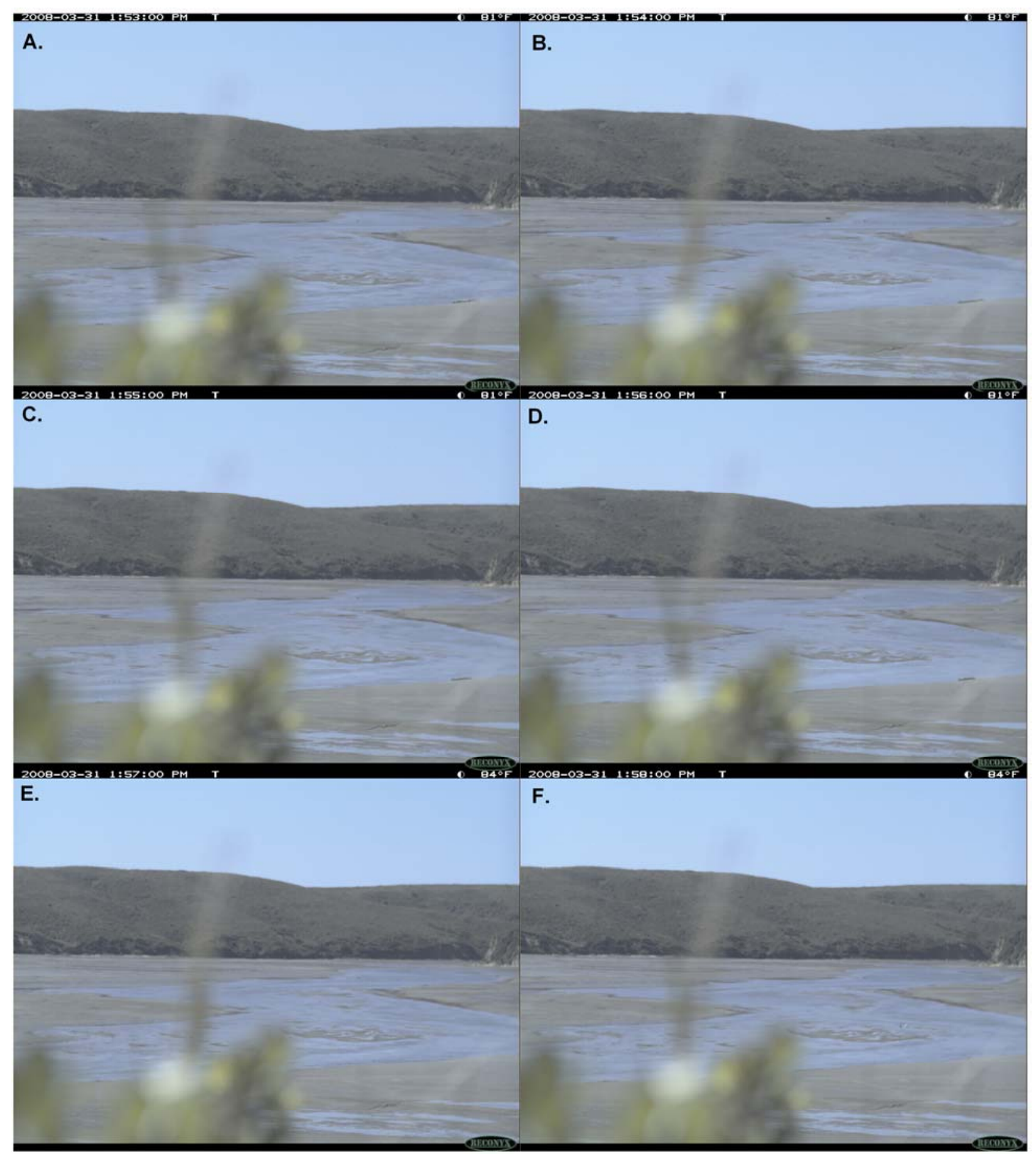

Figure 2. A series of photographs of a seal flushing event on March 31, 2008, at the Oyster Bar site within Drakes Estero. A, Seals hauled out onshore (lower right corner). B, Seals hauled out onshore with the appearance of an unidentified black object on the shore opposite to the seals. $\mathrm{C}$, Black object is gone and seals remained hauled out. D, Seals remained hauled out. E, All seals flush from the haulout site. F, No seals evident. Photographs were taken at 1-minute intervals. 


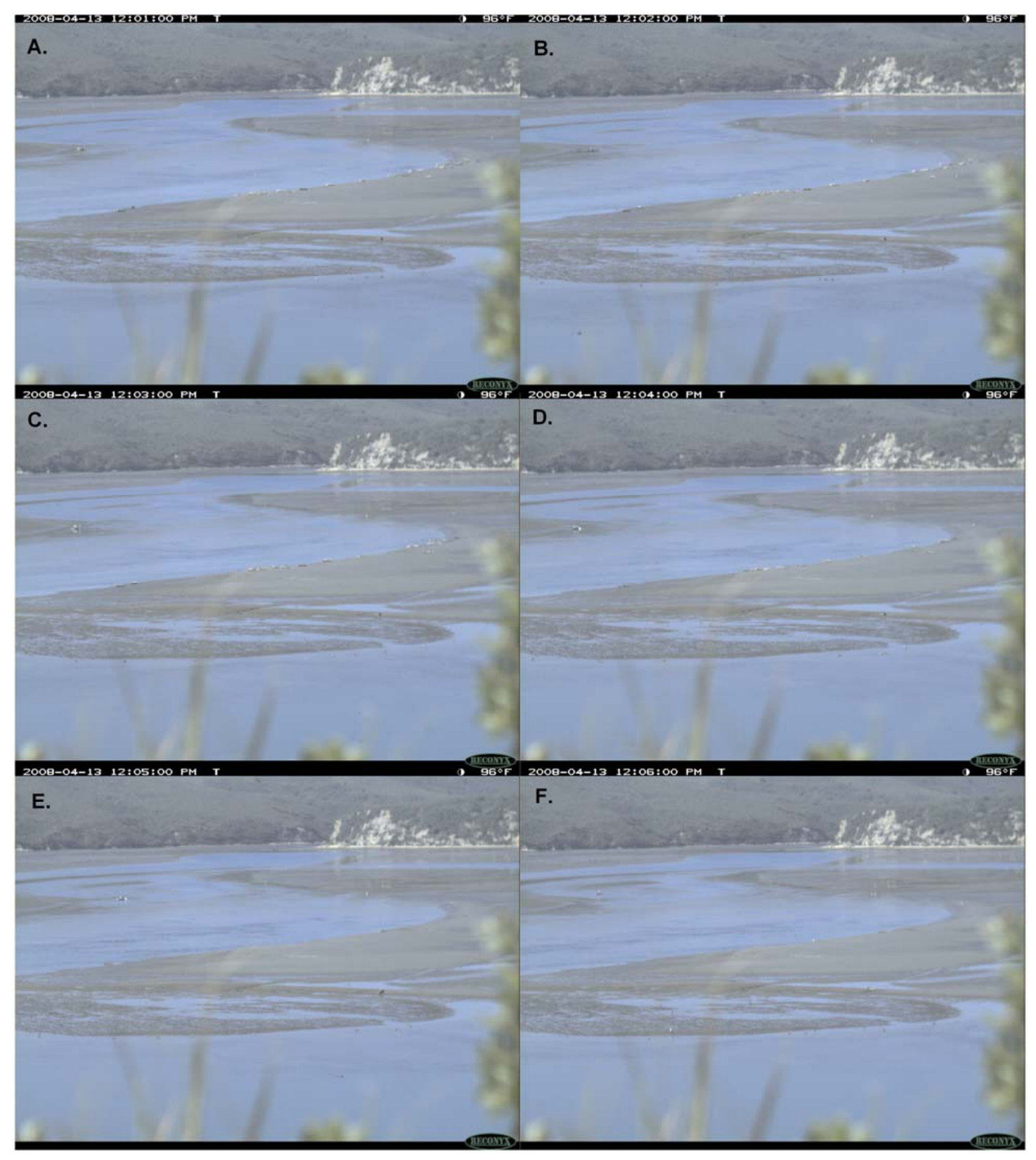

Figure 3. A series of photographs of a seal flushing event on April 13, 2008, beginning at12:01 p.m.at the Oyster Bar site within Drakes Estero. A, Seals hauled out along shore as a kayaker approaches. B, Seals remained hauled out as kayaker comes closer. C, Kayaker continues to approach hauled out seals without movement of seals. D, Some seals begin flushing from shore in the presence of the kayaker. E, All seals have flushed and kayaker remains in view. F, All seals remained flushed as kayaker leaves haulout site. Photographs were taken at 1-minute intervals. 


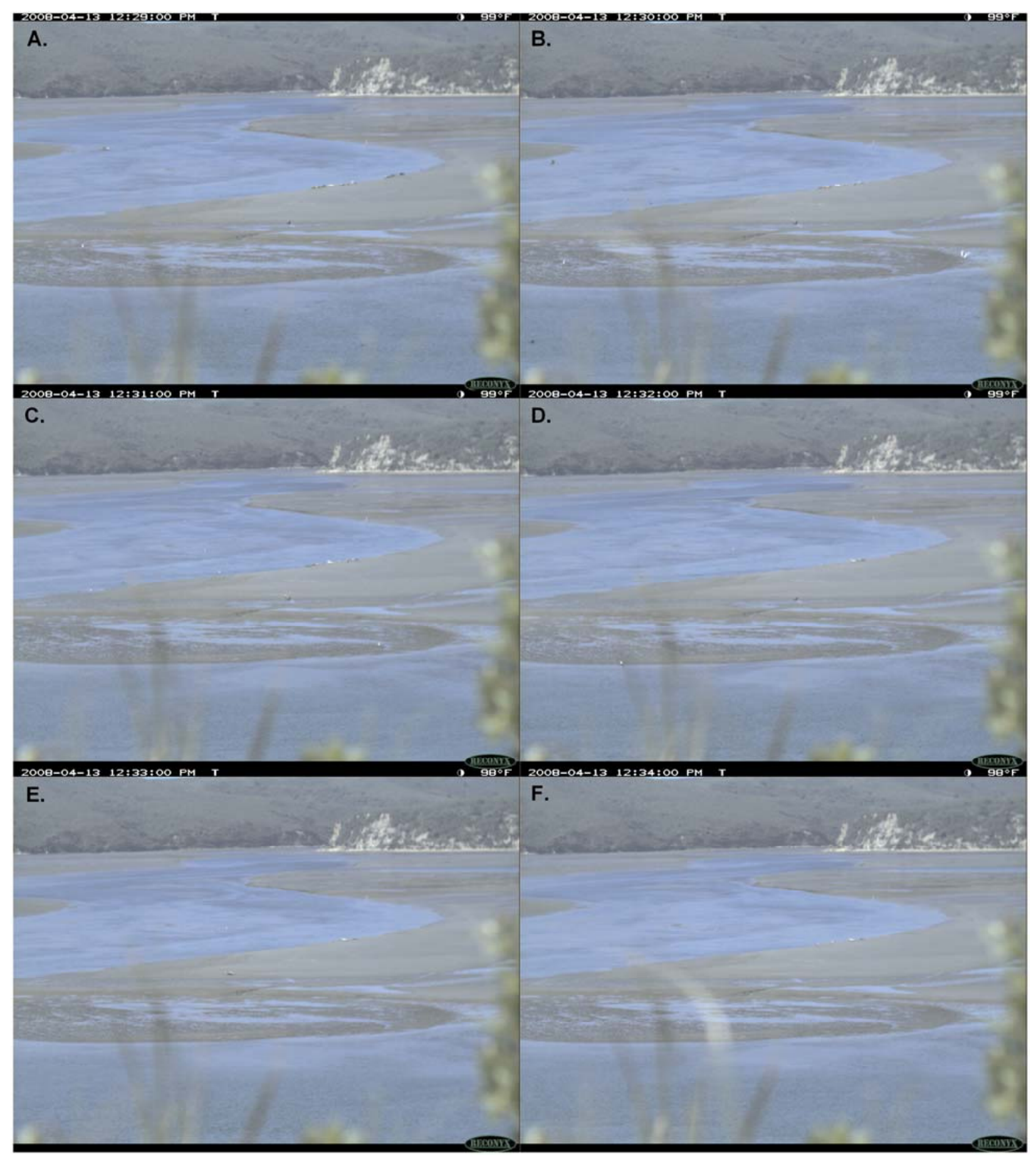

Figure 4. A series of photographs of a seal flushing event on April 13, 2008, beginning at 12:29 p.m. at the Oyster Bar site within Drakes Estero. A, Seals hauled out along shore as a kayaker approaches. B, Some seals begin to leave hauled out area as kayaker comes closer. C, Kayaker is no longer in view and seals continue to move. D, More seals have flushed into the water, with a few remaining seals hauled out. E, A few seals remain on shore. F, Some seals begin to return to haulout site. Photographs were taken at 1-minute intervals. 


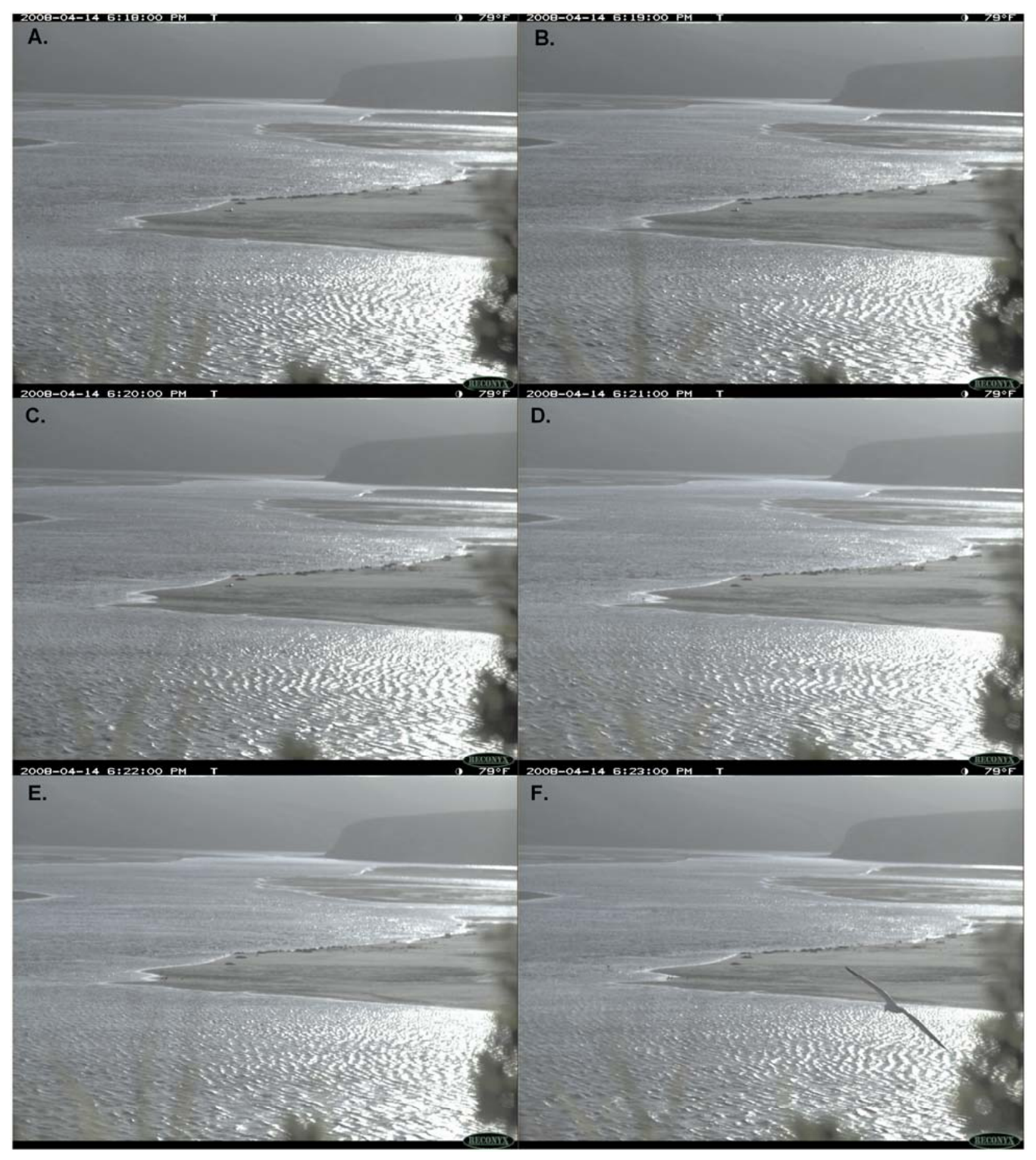

Figure 5. A series of photographs of a seal flushing event on April 14, 2008, at the Oyster Bar site within Drakes Estero. A, Seals hauled out along the shore. B, Seals still hauled out along the shore. C, Unidentified birds begin to land on sandbar near some hauled-out seals. D, A group of seals near the birds flush into the water. E, Birds remain on shore where some seals are still hauled out. F, Bird and seal activity does not appear to change. Photographs were taken at 1-minute intervals. 


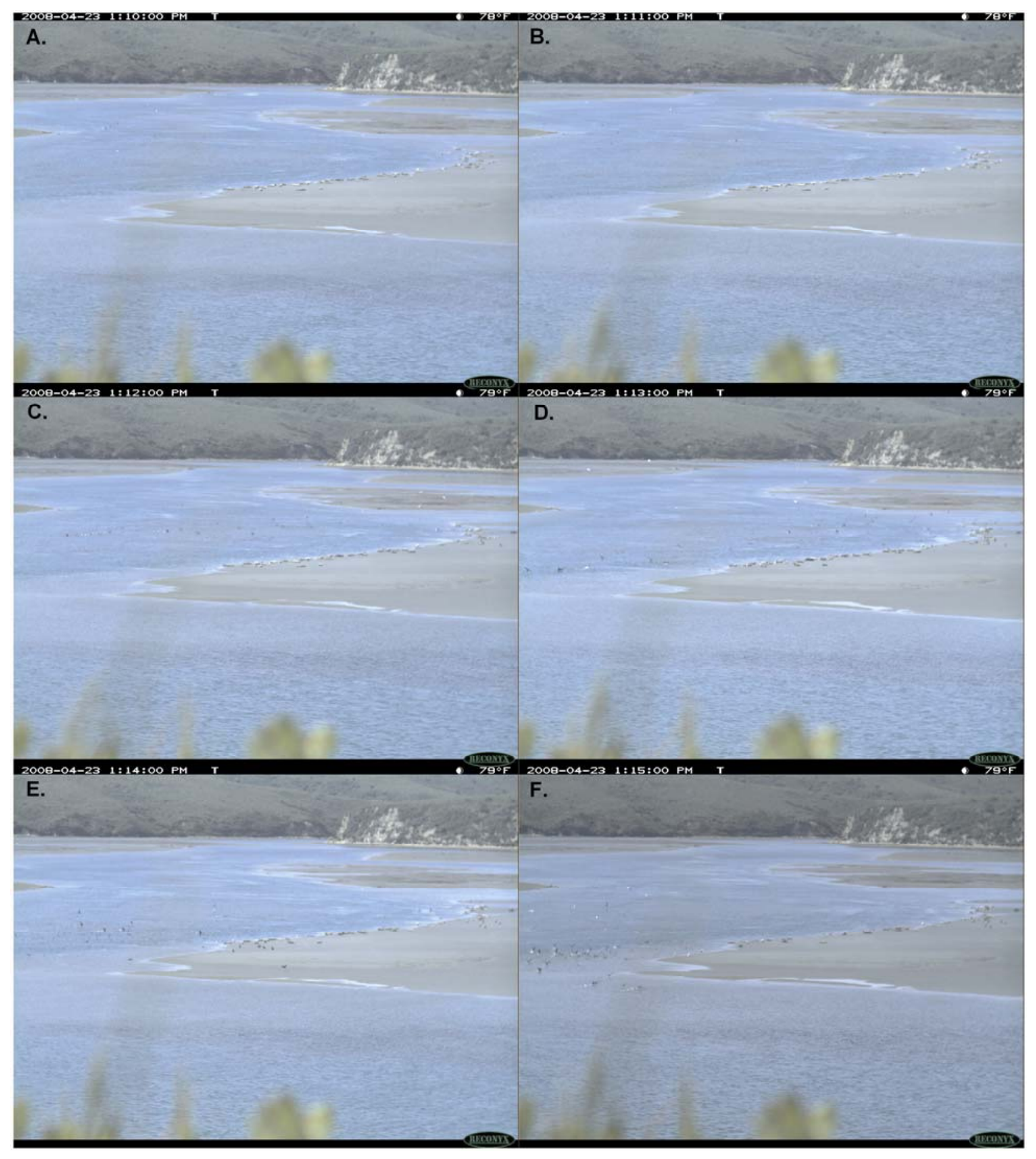

Figure 6. A series of photographs of a seal flushing event on April 23, 2008, at the Oyster Bar site within Drakes Estero. A, Seals hauled out along the shore while a boat with people associated with it is docked on the opposite channel (far upper left corner). B, Boat, people, and seal activity do not appear to change. C, Bird activity near the seals increases. D, Some birds land on the haulout site near the seals. E, Some seals begin to flush from the haulout site as birds continue to be active near and on the shore. F, More seals flush from the haulout site as bird activity continues (boat and people remain on opposite shore). Photographs were taken at 1minute intervals. 


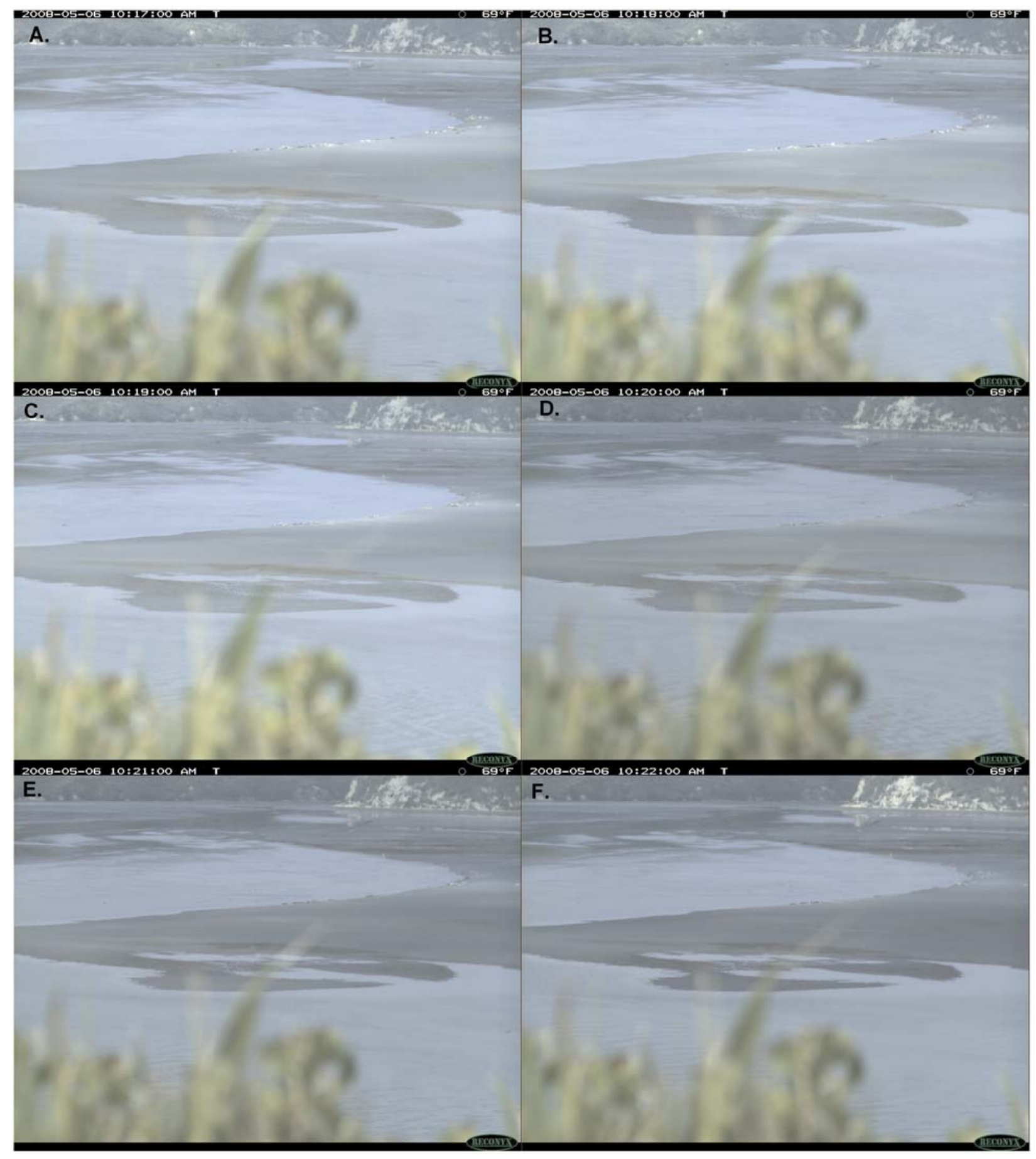

Figure 7. A series of photographs of a seal flushing event on May 6, 2008, at the Oyster Bar site within Drakes Estero. A, Seals hauled out along the shore while a boat is present along opposite shore (boat arrived approximately 80 minutes prior to photograph). B, Seal and boat activity do not change. C, About a third of the seals flush from the haulout site. D-F, Seal and boat activity do not change. (No people were visible within the camera view during the flushing event.) Photographs were taken at 1-minute intervals. 


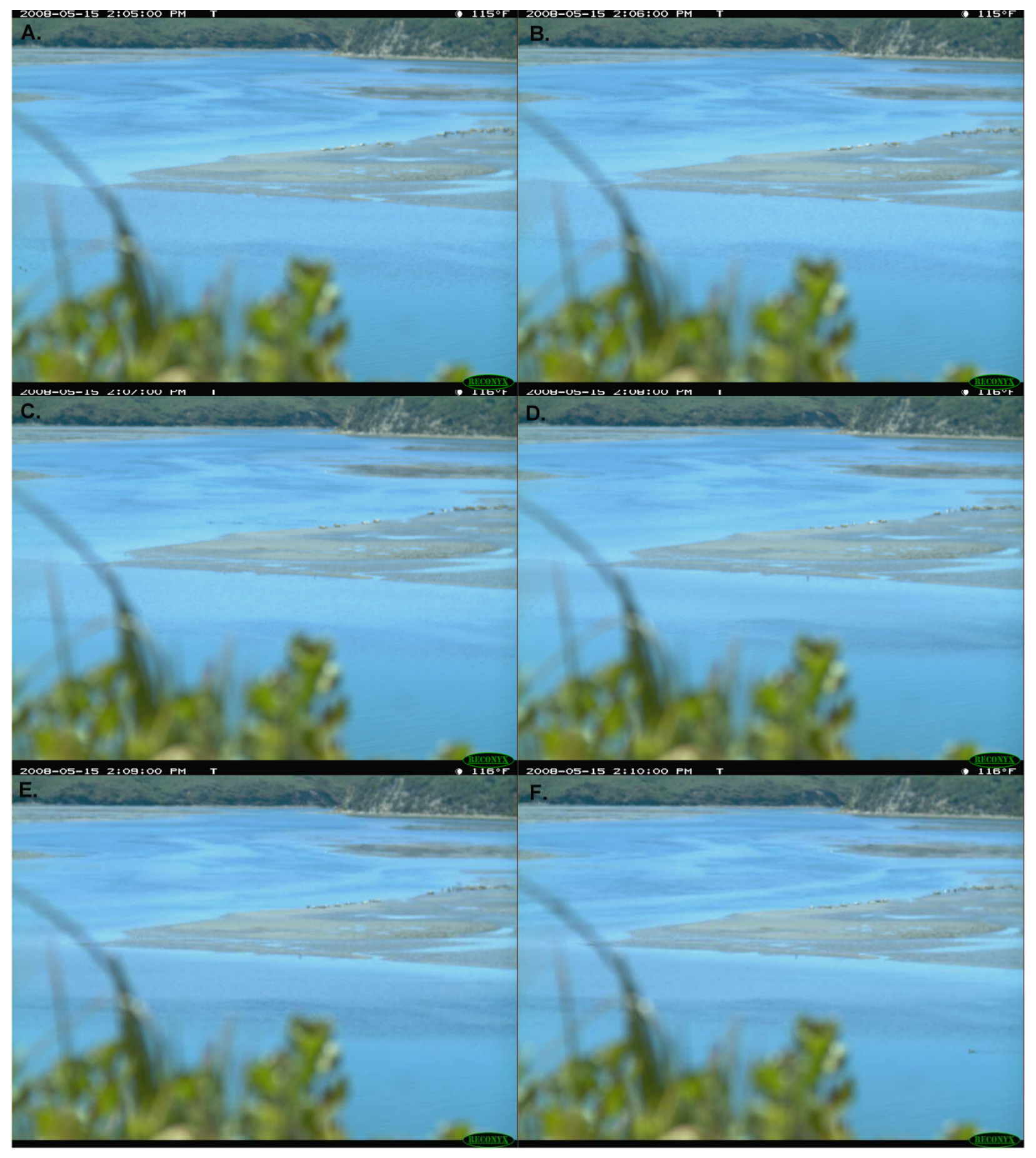

Figure 8. A series of photographs of a seal flushing event on May 15, 2008, at the Oyster Bar site within Drakes Estero. A, Seals hauled out along the shore and a boat docked along the far back channel (upper right corner). B, Slight increase in seal activity; boat remains along the far back channel. C, Some seals flush into the water with their heads visible; the boat has left the channel. D, Some seals remain in water, moving around. E, Seals begin to return to shore. F, Most of the seals have returned to the haulout site. Photographs were taken at 1-minute intervals. 


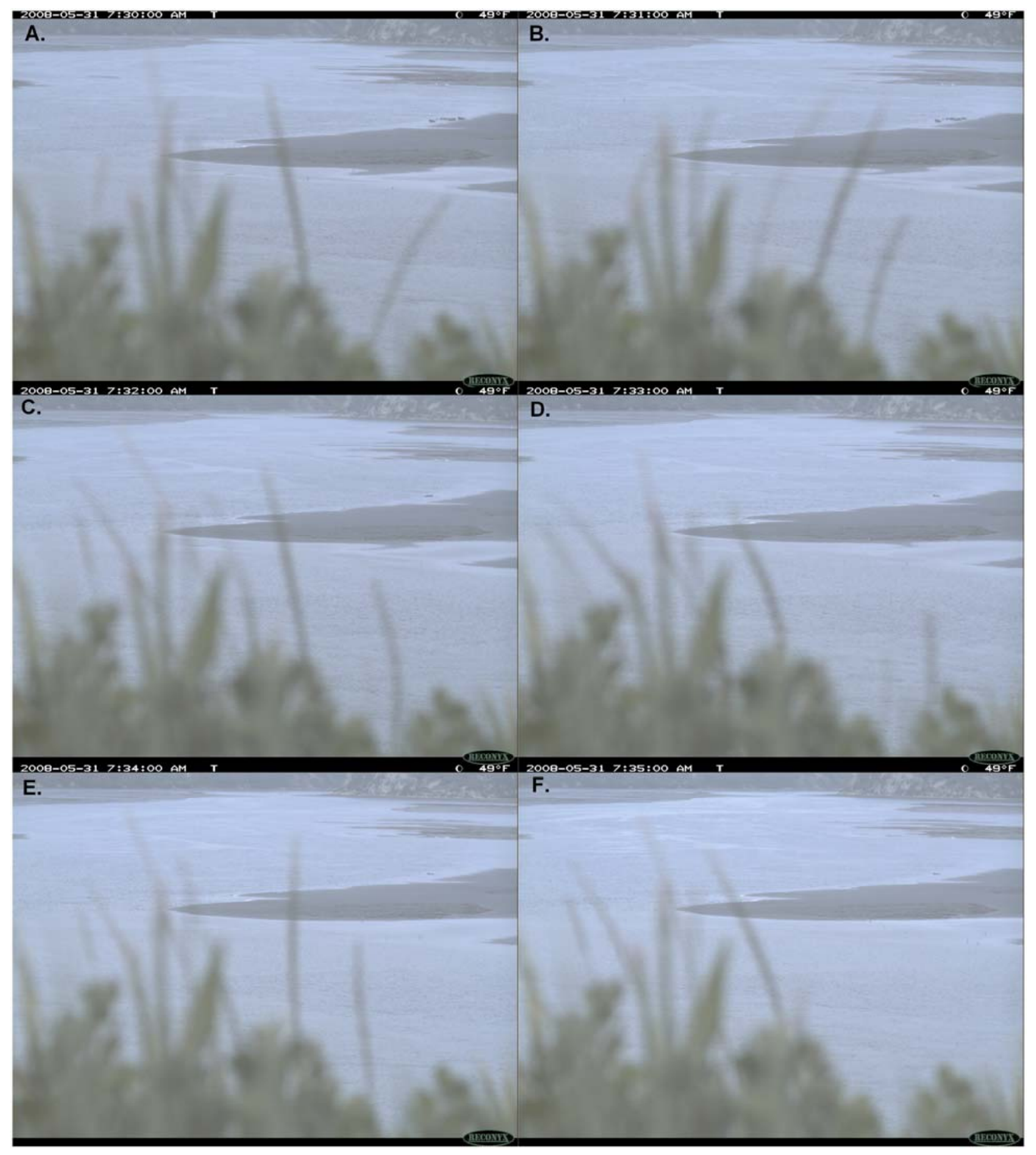

Figure 9. A series of photographs of a seal flushing event on May 31, 2008, at the Oyster Bar site within Drakes Estero. A, Seals hauled out along the shore while the tide is rising. B, Seals becoming slightly inundated by the tide but remain hauled out. C, All seals but one flush from the shore, with no visible stimuli present. D, A single seal remains hauled out on the shore. EF, No change in seal activity. Photographs were taken at 1-minute intervals. 


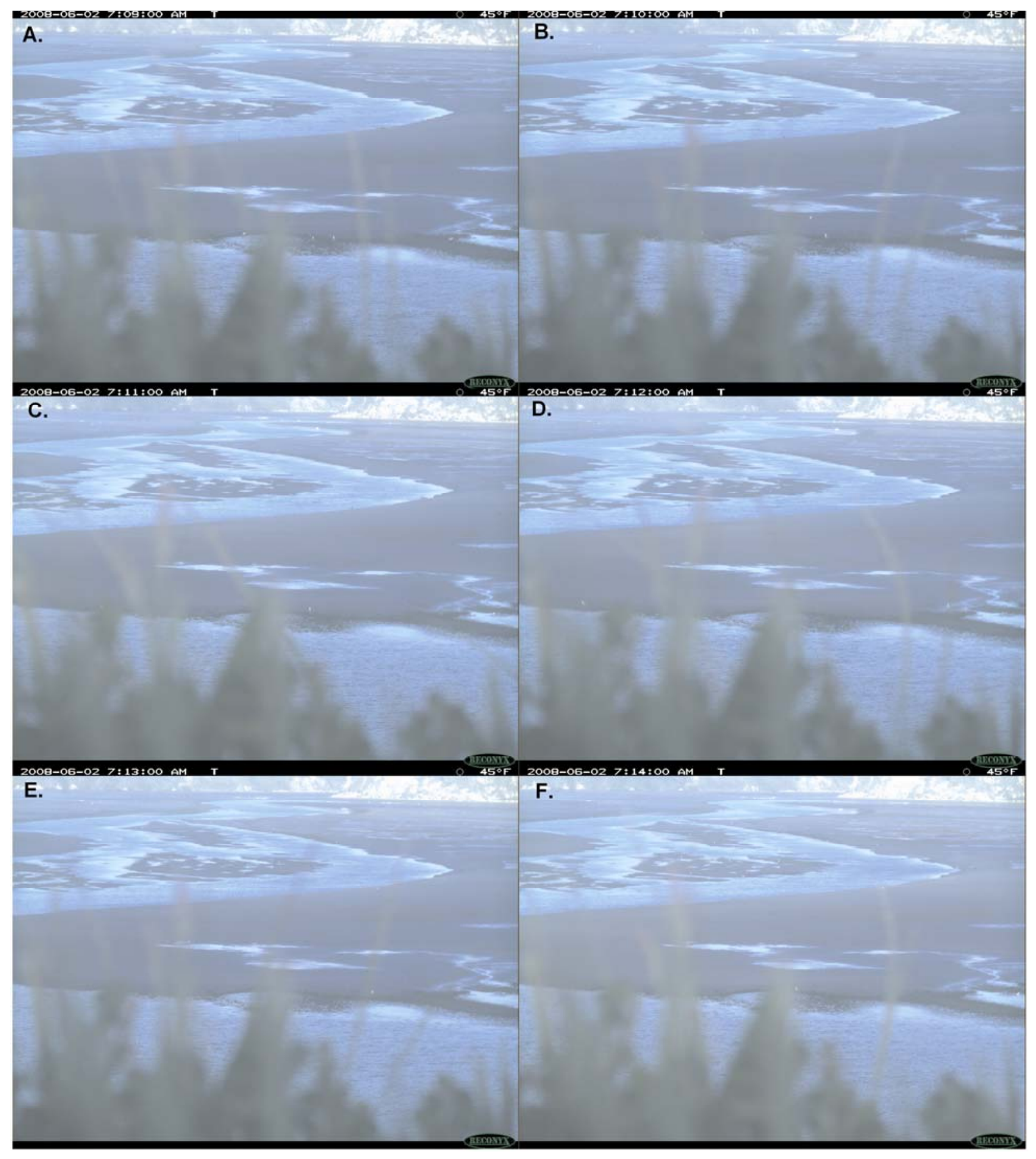

Figure 10. A series of photographs of a seal flushing event on June 2, 2008, at the Oyster Bar site within Drakes Estero. A, Seals hauled out along the shore. B, No change in seal activity. C, All seals flush from haulout site, with no visible stimuli. D, No seals present on shore. E-F, No change in activity. Photographs were taken at 1-minute intervals. 


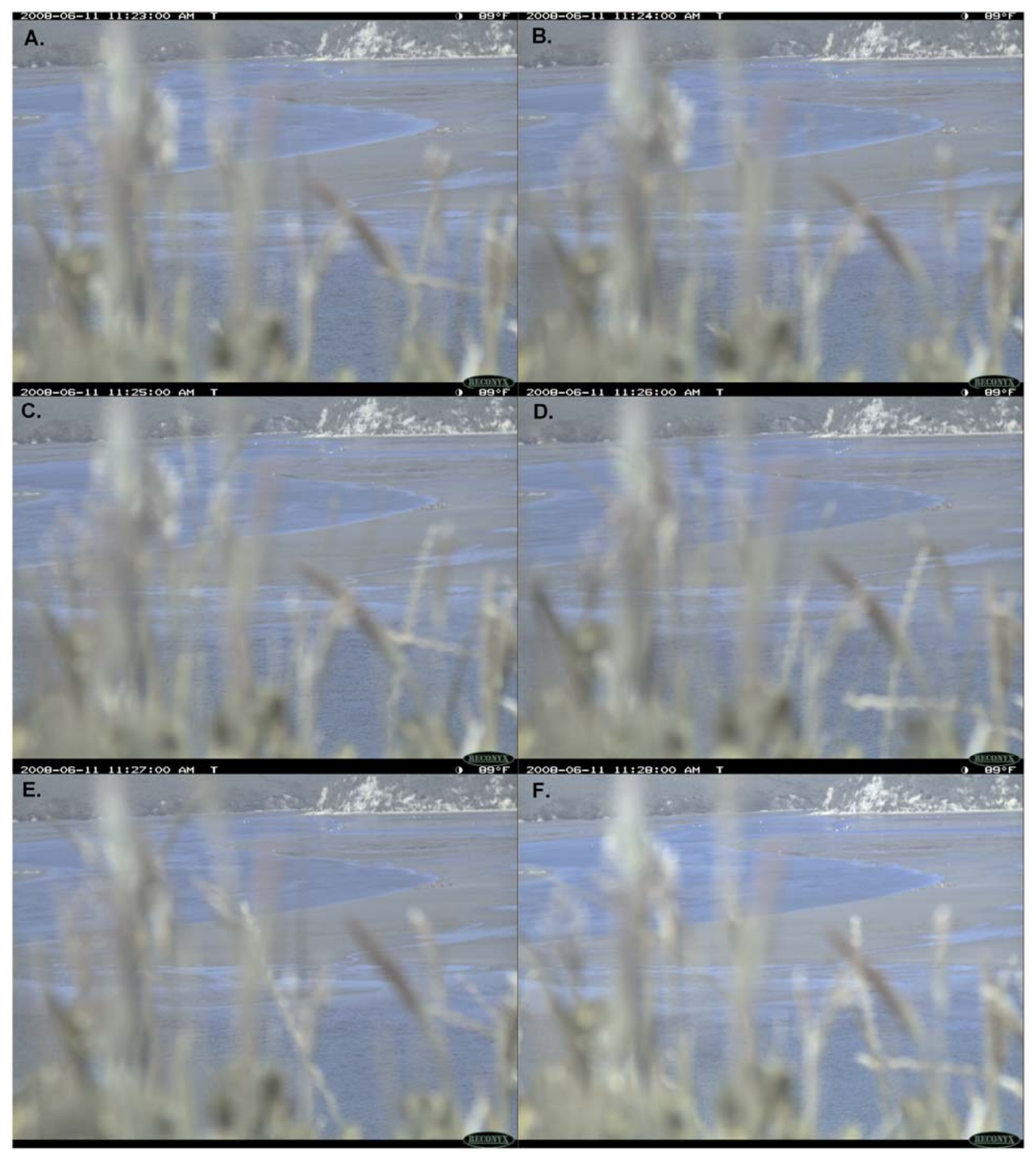

Figure 11. A series of photographs of a seal flushing event on June 11, 2008, at the Oyster Bar site within Drakes Estero. A, Seals hauled out along the shore. B, Not change in seal activity. $\mathrm{C}$, A sudden, brief movement of seals toward the water's edge. D, Seals remain near water's edge. E, No change in seal activity. F, Boat enters frame landing on the shore opposite to the hauled out seals; seal activity does not change. Photographs were taken at 1-minute intervals. 
Appendix 1. Summary analysis of 3,140 photographs from 75 potential disturbance events to hauled out harbor seals in Drakes Estero. 


\begin{tabular}{|c|c|c|c|c|c|c|c|c|c|c|c|}
\hline Date & Stimulus & $\begin{array}{l}\text { Number of } \\
\text { Photos } \\
\text { Reviewed }\end{array}$ & \begin{tabular}{|c|} 
Evidence of \\
Seals Flushing \\
\end{tabular} & $\begin{array}{c}\text { Connection Between Stimulus } \\
\text { and Seal Flushing }\end{array}$ & Boat & $\begin{array}{c}\text { Camera } \\
\text { Serviced } \\
\end{array}$ & Kayak & Birds & Unknown & $\begin{array}{l}\text { Flushing } \\
\text { Events }\end{array}$ & Comments \\
\hline $03 / 26 / 08$ & camera serviced & 93 & no & & & 1 & & & & 0 & $\begin{array}{l}\text { Camera service; poor camera focus; no evidence of } \\
\text { disturbance to seals }\end{array}$ \\
\hline $03 / 27 / 08$ & boat & 40 & no & & 1 & & & & & 0 & $\begin{array}{l}\text { Boat visits area; people walking; poor camera focus; } \\
\text { no evidence of disturbance to seals }\end{array}$ \\
\hline $03 / 27 / 08$ & boat & 21 & no & & 1 & & & & & 0 & $\begin{array}{l}\text { Boat visits area; no people; no evidence of } \\
\text { disturbance to seals }\end{array}$ \\
\hline $03 / 27 / 08$ & camera serviced & 36 & no & & & 1 & & & & 0 & $\begin{array}{l}\text { Camera serviced; seals in camera view before } \\
\text { servicing; no seals in changed camera view after } \\
\text { servicing; no evidence of disturbance to seals }\end{array}$ \\
\hline $03 / 31 / 08$ & boat & 89 & no & & 1 & & & & & 0 & $\begin{array}{l}\text { Boat visits area; people walking; poor visibility; no } \\
\text { evidence of disturbance to seals }\end{array}$ \\
\hline $03 / 31 / 08$ & camera serviced & 23 & no & & & 1 & & & & 0 & $\begin{array}{l}\text { Camera serviced; seals partially obscured by camera } \\
\text { angle; poor camera focus; no evidence of disturbance } \\
\text { to seals }\end{array}$ \\
\hline 03/31/08 & black object & 24 & yes & Black object on opposite bank? & & & & & 1 & 1 & $\begin{array}{l}\text { Black object on shore } 3 \text { minutes prior to flushing; } \\
\text { small group ( }<10) \text { of seals all flush; no evidence of } \\
\text { human stimuli; many gulls and seabirds in area }\end{array}$ \\
\hline 04/05/08 & birds & 21 & no & & & & & 1 & & 0 & $\begin{array}{l}\text { Lots of gulls and seabirds present; poor camera focus; } \\
\text { no evidence of disturbance to seals }\end{array}$ \\
\hline 04/05/08 & boat & 53 & no & & 1 & & & & & 0 & $\begin{array}{l}\text { Boat visits area; people walking; poor camera focus; } \\
\text { water rising and seals correlatively leaving; no } \\
\text { evidence of disturbance to seals }\end{array}$ \\
\hline $04 / 07 / 08$ & camera serviced & 24 & no & & & 1 & & & & 0 & $\begin{array}{l}\text { Camera serviced and moved; poor camera focus and } \\
\text { resolution; no evidence of disturbance to seals }\end{array}$ \\
\hline $04 / 08 / 08$ & boat & 25 & no & & 1 & & & & & 0 & $\begin{array}{l}\text { Boat present; no people walking; high tide; seals } \\
\text { partially submerged and leaving as water rises; no } \\
\text { evidence of disturbance to seals }\end{array}$ \\
\hline $04 / 10 / 08$ & boat & 181 & no & & 1 & & & & & 0 & $\begin{array}{l}\text { Boat visits area; people walking; gulls and other } \\
\text { seabirds present; low tide; no evidence of disturbance } \\
\text { to seals }\end{array}$ \\
\hline 04/10/08 & camera serviced & 22 & no & & & 1 & & & & 0 & $\begin{array}{l}\text { Camera serviced and moved; no evidence of } \\
\text { disturbance to seals }\end{array}$ \\
\hline $04 / 10 / 08$ & boat & 53 & no & & 1 & & & & & 0 & $\begin{array}{l}\text { Boat visits area; people walking; no evidence of } \\
\text { disturbance to seals }\end{array}$ \\
\hline $04 / 11 / 08$ & boat & 31 & no & & 1 & & & & & 0 & $\begin{array}{l}\text { Boat visits area; no people walking; poor visibility; fog } \\
\text { and plants obscure view; seals hauling out as tide } \\
\text { falls; no evidence of disturbance to seals }\end{array}$ \\
\hline $04 / 11 / 08$ & boat & 36 & no & & 1 & & & & & 0 & $\begin{array}{l}\text { Boat visits area; people walking; no evidence of } \\
\text { disturbance to seals }\end{array}$ \\
\hline $04 / 12 / 08$ & boat & 24 & no & & 1 & & & & & 0 & $\begin{array}{l}\text { Boat visits area; no people walking; high tide; seals } \\
\text { partially submerged; no evidence of disturbance to } \\
\text { seals }\end{array}$ \\
\hline
\end{tabular}




\begin{tabular}{|c|c|c|c|c|c|c|c|c|c|c|c|}
\hline Date & Stimulus & $\begin{array}{c}\text { Number of } \\
\text { Photos } \\
\text { Reviewed }\end{array}$ & $\begin{array}{c}\text { Evidence of } \\
\text { Seals Flushing }\end{array}$ & $\begin{array}{c}\begin{array}{c}\text { Connection Between Stimulus } \\
\text { and Seal Flushing }\end{array} \\
\end{array}$ & Boat & $\begin{array}{c}\text { Camera } \\
\text { Serviced } \\
\end{array}$ & Kayak & Birds & Unknown & $\begin{array}{l}\text { Flushing } \\
\text { Events }\end{array}$ & Comments \\
\hline 04/12/08 & boat & 35 & no & & 1 & & & & & 0 & $\begin{array}{l}\text { Boat visits area; no people walking; high tide; seals } \\
\text { mostly submerged; no evidence of disturbance to } \\
\text { seals }\end{array}$ \\
\hline $04 / 12 / 08$ & boat & 30 & no & & 1 & & & & & 0 & $\begin{array}{l}\text { Boat visits area; people walking; high tide; haulout } \\
\text { habitat being exposed and seals starting to haul out; } \\
\text { no evidence of disturbance to seals }\end{array}$ \\
\hline 04/12/08 & boat & 85 & no & & 1 & & & & & 0 & $\begin{array}{l}\text { Boat visits area; people walking; very poor camera } \\
\text { focus and resolution; no evidence of disturbance to } \\
\text { seals }\end{array}$ \\
\hline $04 / 13 / 08$ & kayak & 32 & yes & yes & & & 1 & & & 1 & $\begin{array}{l}\text { Kayak visits area; poor focus and camera resolution; } \\
\text { small group of seals present; gulls and other seabirds } \\
\text { present; kayak approaches group to within } 100 \\
\text { meters or less; all seals flush; seals start hauling out } \\
\text { within } 10 \text { minutes after kayak disappears }\end{array}$ \\
\hline $04 / 13 / 08$ & kayak & 24 & yes & yes & & & 1 & & & 1 & $\begin{array}{l}\text { Kayak visits area; kayak approaches within } 100 \\
\text { meters of small group of seals; all but } 2 \text { seals flush } \\
\text { into water }\end{array}$ \\
\hline $04 / 14 / 08$ & camera serviced & 21 & no & & & 1 & & & & 0 & Camera moved; no evidence of disturbance to seals \\
\hline $04 / 14 / 08$ & birds & 22 & yes & Birds landing? & & & & 1 & & 1 & $\begin{array}{l}\text { Birds arrive in area; poor camera focus and visibility; a } \\
\text { few seals in small group flush into water when birds } \\
\text { arrive from area off camera; no evidence of human } \\
\text { presence in the estuary }\end{array}$ \\
\hline $04 / 16 / 08$ & boat & 32 & no & & 1 & & & & & 0 & $\begin{array}{l}\text { Boat visits area; no people walking; high tide; poor } \\
\text { camera focus and resolution; the few seals present } \\
\text { are partially submerged; no evidence of disturbance } \\
\text { to seals }\end{array}$ \\
\hline 04/16/08 & boat & 29 & no & & 1 & & & & & 0 & $\begin{array}{l}\text { Boat visits area; no people walking; high water; poor } \\
\text { camera focus; no evidence of disturbance to seals }\end{array}$ \\
\hline 04/17/08 & camera serviced & 21 & no & & & 1 & & & & 0 & $\begin{array}{l}\text { Camera serviced; poor visibility; fog; tide just falling; } \\
\text { gulls and seabirds present; seals are partially } \\
\text { submerged; no evidence of disturbance to seals }\end{array}$ \\
\hline $04 / 23 / 08$ & boat/birds & 37 & yes & $\begin{array}{l}\text { Not clear, boat present but } \\
\text { flushing seems related to birds } \\
\text { landing }\end{array}$ & 1 & & & 1 & & 1 & $\begin{array}{l}\text { Boat visits area; people walking; lots of gulls and } \\
\text { other seabirds present; seabirds flying toward seals } \\
\text { and boat beyond; } 1 / 4 \text { to } 1 / 3 \text { of seals flush into water; } \\
\text { seabirds continue arriving from near camera; seals } \\
\text { seem to be responding to birds }\end{array}$ \\
\hline $04 / 23 / 08$ & boat & 36 & no & & 1 & & & & & 0 & $\begin{array}{l}\text { Boat visits area; people walking; tide rising; seals } \\
\text { partially submerged; no evidence of disturbance to } \\
\text { seals }\end{array}$ \\
\hline
\end{tabular}




\begin{tabular}{|c|c|c|c|c|c|c|c|c|c|c|c|}
\hline Date & Stimulus & $\begin{array}{l}\text { Number of } \\
\text { Photos } \\
\text { Reviewed }\end{array}$ & $\begin{array}{c}\text { Evidence of } \\
\text { Seals Flushing }\end{array}$ & $\begin{array}{c}\text { Connection Between Stimulus } \\
\text { and Seal Flushing }\end{array}$ & Boat & $\begin{array}{c}\text { Camera } \\
\text { Serviced }\end{array}$ & Kayak & Birds & Unknown & $\begin{array}{c}\text { Flushing } \\
\text { Events }\end{array}$ & Comments \\
\hline $04 / 24 / 08$ & boat & 36 & no & & 1 & & & & & 0 & $\begin{array}{l}\text { Boat visits area; people walking; tide rising; poor } \\
\text { camera focus and resolution; some seals leaving as } \\
\text { water submerges them; no evidence of disturbance to } \\
\text { seals }\end{array}$ \\
\hline $04 / 25 / 08$ & camera serviced & 27 & no & & & 1 & & & & 0 & $\begin{array}{l}\text { Camera serviced and moved; very poor camera focus } \\
\text { and resolution; no evidence of disturbance to seals }\end{array}$ \\
\hline $04 / 26 / 08$ & boat & 52 & no & & 1 & & & & & 0 & $\begin{array}{l}\text { Boat visits area; people walking; poor camera focus } \\
\text { and resolution; no evidence of disturbance to seals }\end{array}$ \\
\hline 04/26/08 & boat & 42 & no & & 1 & & & & & 0 & $\begin{array}{l}\text { Boat visits area; people walking; no evidence of } \\
\text { disturbance to seals }\end{array}$ \\
\hline 04/29/08 & boat & 27 & no & & 1 & & & & & 0 & $\begin{array}{l}\text { Boat visits area; people walking; no evidence of } \\
\text { disturbance to seals }\end{array}$ \\
\hline 04/29/08 & camera serviced & 21 & no & & & 1 & & & & 0 & $\begin{array}{l}\text { Camera serviced and moved; no evidence of } \\
\text { disturbance to seals }\end{array}$ \\
\hline $04 / 30 / 08$ & boat & 37 & no & & 1 & & & & & 0 & $\begin{array}{l}\text { Boat visits area; people walking; tide high and falling; } \\
\text { a few seals present are partially submerged; no } \\
\text { evidence of disturbance to seals }\end{array}$ \\
\hline 05/01/08 & boat & 78 & no & & 1 & & & & & 0 & $\begin{array}{l}\text { Boat visits area; no people walking; high tide; no } \\
\text { haulout habitat available; a few seals partially } \\
\text { submerged; no evidence of disturbance to seals }\end{array}$ \\
\hline 05/01/08 & black object & 21 & no & & & & & & 1 & 0 & $\begin{array}{l}\text { Unknown dark object in water; gulls and other } \\
\text { seabirds present; no evidence of disturbance to seals }\end{array}$ \\
\hline 05/01/08 & camera serviced & 21 & no & & & 1 & & & & 0 & $\begin{array}{l}\text { Camera serviced; very poor camera focus and } \\
\text { resolution; low tide; gulls and other seabirds present; } \\
\text { no evidence of disturbance to seals }\end{array}$ \\
\hline $05 / 02 / 08$ & boat & 41 & no & & 1 & & & & & 0 & $\begin{array}{l}\text { Boat visits area; people walking; very poor focus and } \\
\text { resolution; tide falling; no evidence of disturbance to } \\
\text { seals }\end{array}$ \\
\hline 05/03/08 & boat & 37 & no & & 1 & & & & & 0 & $\begin{array}{l}\text { Boat visits area; people walking; light fog; poor } \\
\text { camera focus; tide rising; seals partially submerged; } \\
\text { no evidence of disturbance to seals }\end{array}$ \\
\hline 05/03/08 & boat & 45 & no & & 1 & & & & & 0 & $\begin{array}{l}\text { Boat visits area; people walking; tide high and falling; } \\
\text { few seals present partially submerged; no evidence of } \\
\text { disturbance to seals }\end{array}$ \\
\hline 05/03/08 & birds & 21 & no & & & & & 1 & & 0 & $\begin{array}{l}\text { Birds swimming in group along shoreline; lots of gulls } \\
\text { and seabirds roosting and on water; no evidence of } \\
\text { disturbance to seals }\end{array}$ \\
\hline 05/05/08 & boat/camera & 63 & no & & 1 & 1 & & & & 0 & $\begin{array}{l}\text { Boat visits area; people walking; camera } \\
\text { maintenance; tide high and rising; very poor camera } \\
\text { focus; no evidence of disturbance to seals }\end{array}$ \\
\hline $05 / 05 / 08$ & boat & 94 & no & & 1 & & & & & 0 & $\begin{array}{l}\text { Boat visits area; people walking; high tide; very poor } \\
\text { camera focus; no evidence of disturbance to seals }\end{array}$ \\
\hline
\end{tabular}




\begin{tabular}{|c|c|c|c|c|c|c|c|c|c|c|c|}
\hline Date & Stimulus & $\begin{array}{l}\text { Number of } \\
\text { Photos } \\
\text { Reviewed }\end{array}$ & $\begin{array}{l}\text { Evidence of } \\
\text { Seals Flushing }\end{array}$ & $\begin{array}{c}\text { Connection Between Stimulus } \\
\text { and Seal Flushing }\end{array}$ & Boat & $\begin{array}{c}\text { Camera } \\
\text { Serviced }\end{array}$ & Kayak & Birds & Unknown & $\begin{array}{l}\text { Flushing } \\
\text { Events }\end{array}$ & Comments \\
\hline 05/06/08 & boat & 195 & yes & $\begin{array}{l}1 / 3 \text { of seals flushed, cause not } \\
\text { clear, likely not related to boat }\end{array}$ & 1 & & & & & 1 & $\begin{array}{l}\text { Boat visits area; people walking; low tide; } 1 / 3 \text { of seals } \\
\text { hauled out flush; begin hauling out again within } 10 \\
\text { minutes; not clear if human stimuli related to seal } \\
\text { flushing; gulls and other seabirds roosting and in } \\
\text { water }\end{array}$ \\
\hline $05 / 06 / 08$ & boat & 23 & no & & 1 & & & & & 0 & $\begin{array}{l}\text { Boat visits area; people walking; poor camera focus; a } \\
\text { few seals present are partially submerged; no } \\
\text { evidence of disturbance to seals }\end{array}$ \\
\hline 05/07/08 & boat & 254 & no & & 1 & & & & & 0 & $\begin{array}{l}\text { Boat visits area; people walking; very low tide; poor } \\
\text { camera focus; large number of roosting seabirds; no } \\
\text { evidence of disturbance to seals }\end{array}$ \\
\hline 05/13/08 & camera serviced & 12 & no & & & 1 & & & & 0 & $\begin{array}{l}\text { Camera serviced; mid-tide; poor camera focus; no } \\
\text { evidence of disturbance to seals }\end{array}$ \\
\hline 05/13/08 & boat & 68 & no & & 1 & & & & & 0 & $\begin{array}{l}\text { Boat visits area; no people walking; tide falling; poor } \\
\text { camera focus; lots of birds flying and flushing from } \\
\text { near camera side; no evidence of disturbance to seals }\end{array}$ \\
\hline $05 / 15 / 08$ & boat & 31 & yes & & 1 & & & & & 1 & $\begin{array}{l}\text { Boat visits area; people walking; very poor camera } \\
\text { focus; some seals flush into water just after boat } \\
\text { leaves the area }\end{array}$ \\
\hline 05/15/08 & camera serviced & 21 & no & & & 1 & & & & 0 & $\begin{array}{l}\text { Camera serviced; extremely poor camera focus; no } \\
\text { evidence of disturbance to seals }\end{array}$ \\
\hline 05/19/08 & camera serviced & 23 & no & & & 1 & & & & 0 & $\begin{array}{l}\text { Camera serviced; poor camera focus; no evidence of } \\
\text { disturbance to seals }\end{array}$ \\
\hline $05 / 22 / 08$ & camera serviced & 23 & no & & & 1 & & & & 0 & Camera serviced; no evidence of disturbance to seals \\
\hline $05 / 22 / 08$ & boat & 40 & no & & 1 & & & & & 0 & $\begin{array}{l}\text { Boat visits area; people walking; water rising; no } \\
\text { evidence of disturbance to seals }\end{array}$ \\
\hline $05 / 23 / 08$ & boat & 57 & no & & 1 & & & & & 0 & $\begin{array}{l}\text { Boat visits area; no people walking; poor camera } \\
\text { focus; gulls and seabirds scattered and mobile; no } \\
\text { evidence of disturbance to seals }\end{array}$ \\
\hline 05/23/08 & camera serviced & 62 & no & & & 1 & & & & 0 & $\begin{array}{l}\text { Camera serviced and moved; high tide; very poor } \\
\text { camera focus; seals mostly submerged; no evidence } \\
\text { of disturbances to seals }\end{array}$ \\
\hline 05/27/08 & camera serviced & 22 & no & & & 1 & & & & 0 & $\begin{array}{l}\text { Camera serviced and moved; very poor camera focus; } \\
\text { lots of gulls and other seabirds roosting and rafting; } \\
\text { no evidence of disturbance to seals }\end{array}$ \\
\hline $05 / 27 / 08$ & boat & 35 & no & & 1 & & & & & 0 & $\begin{array}{l}\text { Boat visits area; people walking; extremely poor } \\
\text { camera focus and resolution; tide rising; no evidence } \\
\text { of disturbance to seals }\end{array}$ \\
\hline 05/29/08 & boat & 15 & no & & 1 & & & & & 0 & $\begin{array}{l}\text { Boat visits area; people walking; exceptionally poor } \\
\text { camera focus; tide low slack; no evidence of } \\
\text { disturbance to seals }\end{array}$ \\
\hline
\end{tabular}




\begin{tabular}{|c|c|c|c|c|c|c|c|c|c|c|c|}
\hline Date & Stimulus & $\begin{array}{l}\text { Number of } \\
\text { Photos } \\
\text { Reviewed }\end{array}$ & \begin{tabular}{|c|} 
Evidence of \\
Seals Flushing \\
\end{tabular} & $\begin{array}{c}\begin{array}{c}\text { Connection Between Stimulus } \\
\text { and Seal Flushing }\end{array} \\
\end{array}$ & Boat & $\begin{array}{c}\text { Camera } \\
\text { Serviced } \\
\end{array}$ & Kayak & Birds & Unknown & $\begin{array}{l}\text { Flushing } \\
\text { Events }\end{array}$ & Comments \\
\hline 05/29/08 & camera serviced & 10 & no & & & 1 & & & & 0 & $\begin{array}{l}\text { Camera serviced; very poor camera focus; tide rising; } \\
\text { no evidence of disturbance to seals }\end{array}$ \\
\hline 05/30/08 & boat & 26 & no & & 1 & & & & & 0 & $\begin{array}{l}\text { Boat visits area; people walking; tide rising; poor } \\
\text { camera focus; no evidence of disturbance to seals }\end{array}$ \\
\hline $05 / 31 / 08$ & unknown & 21 & yes & $\begin{array}{l}\text { Not clear, no obvious stimulus } \\
\text { apparent in slide sequence }\end{array}$ & & & & & 1 & 1 & $\begin{array}{l}\text { Tide rising; small number of seals flush ( } 10) \text {; being } \\
\text { submerged but no signs of stimulus; roosting birds } \\
\text { nearby are undisturbed }\end{array}$ \\
\hline $06 / 02 / 08$ & unknown & 21 & yes & $\begin{array}{l}\text { Not clear, no obvious stimulus } \\
\text { apparent in slide sequence }\end{array}$ & & & & & 1 & 1 & $\begin{array}{l}\text { Low tide; very poor camera focus; } 2 \text { small groups of } \\
\text { seals all flush into water; no signs of stimuli to } \\
\text { disturbance; lots of seabirds rafting and roosting }\end{array}$ \\
\hline 06/02/08 & camera serviced & 21 & no & & & 1 & & & & 0 & $\begin{array}{l}\text { Camera serviced and moved; very poor camera focus; } \\
\text { no evidence of disturbance to seals }\end{array}$ \\
\hline 06/03/08 & boat & 39 & no & & 1 & & & & & 0 & $\begin{array}{l}\text { Boat visits area; people walking; very foggy and no } \\
\text { visibility to some clearing; tide rising and submerging } \\
\text { seals; no evidence of disturbance to seals }\end{array}$ \\
\hline 06/04/08 & boat & 38 & no & & 1 & & & & & 0 & $\begin{array}{l}\text { Boat visits area; people walking; strong winds; seals } \\
\text { mostly submerged and departing as tide rises; no } \\
\text { evidence of disturbance to seals }\end{array}$ \\
\hline $06 / 05 / 08$ & boat & 47 & no & & 1 & & & & & 0 & $\begin{array}{l}\text { Boat visits area; people walking; very poor camera } \\
\text { focus; no evidence of disturbance to seals }\end{array}$ \\
\hline $06 / 05 / 08$ & camera serviced & 21 & no & & & 1 & & & & 0 & Camera serviced; no evidence of disturbance to seals \\
\hline $06 / 06 / 08$ & boat & 49 & no & & 1 & & & & & 0 & $\begin{array}{l}\text { Boat visits area; people walking; high tide; slack to } \\
\text { slowly rising with high winds; very poor camera focus; } \\
\text { no evidence of disturbance to seals }\end{array}$ \\
\hline $06 / 11 / 08$ & boat & 34 & yes & $\begin{array}{l}\text { Minor flushing before boat } \\
\text { arrival, cause unknown }\end{array}$ & 1 & & & & & 1 & $\begin{array}{l}\text { Boat visits area; people walking; very poor camera } \\
\text { focus; rafting birds scattered; brief movement of seals } \\
\text { toward water's edge several minutes before boat } \\
\text { arrives but none seen to enter water; no obvious } \\
\text { disturbance to seals }\end{array}$ \\
\hline $06 / 12 / 08$ & boat & 46 & no & & 1 & & & & & 0 & $\begin{array}{l}\text { Boat visits area; people walking; poor camera focus; } \\
\text { high tide; few seals mostly submerged; no evidence of } \\
\text { disturbance to seals }\end{array}$ \\
\hline $06 / 12 / 08$ & camera serviced & 23 & no & & & 1 & & & & 0 & $\begin{array}{l}\text { Camera serviced; very poor camera focus; high tide } \\
\text { with few seals present, mostly submerged; no } \\
\text { evidence of disturbance to seals }\end{array}$ \\
\hline & Total & 3,140 & & & 44 & 21 & 2 & 4 & 4 & 10 & \\
\hline
\end{tabular}

